\title{
The Economics of Intervention: American Overseas Investments and Relations with Underdeveloped Areas, 1890-1950
}

\section{Citation}

Frieden, Jeffry. 1989. The economics of intervention: American overseas investments and relations with underdeveloped areas, 1890-1950. Comparative Studies in Society and History 31, no. 1: 55-80.

\section{Published Version}

doi:10.1017/S0010417500015668

\section{Permanent link}

http://nrs.harvard.edu/urn-3:HUL.InstRepos:10503191

\section{Terms of Use}

This article was downloaded from Harvard University's DASH repository, and is made available under the terms and conditions applicable to Other Posted Material, as set forth at http:// nrs.harvard.edu/urn-3:HUL.InstRepos:dash.current.terms-of-use\#LAA

\section{Share Your Story}

The Harvard community has made this article openly available.

Please share how this access benefits you. Submit a story.

\section{Accessibility}




\title{
The Economics of Intervention: American Overseas Investments and Relations with Underdeveloped Areas, 1890-1950
}

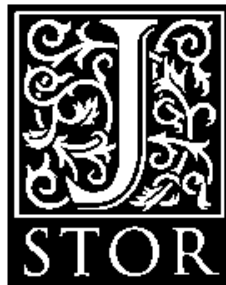

\author{
Jeffry A. Frieden \\ Comparative Studies in Society and History, Volume 31, Issue 1 (Jan., 1989), 55-80.
}

Stable URL:

http:/links.jstor.org/sici?sici=0010-4175\%28198901\%2931\%3A1\%3C55\%3ATEOIAO\%3E2.0.CO\%3B2-M

Your use of the JSTOR archive indicates your acceptance of JSTOR's Terms and Conditions of Use, available at http://www.jstor.org/about/terms.html. JSTOR's Terms and Conditions of Use provides, in part, that unless you have obtained prior permission, you may not download an entire issue of a journal or multiple copies of articles, and you may use content in the JSTOR archive only for your personal, non-commercial use.

Each copy of any part of a JSTOR transmission must contain the same copyright notice that appears on the screen or printed page of such transmission.

Comparative Studies in Society and History is published by Cambridge University Press. Please contact the publisher for further permissions regarding the use of this work. Publisher contact information may be obtained at http://www.jstor.org/journals/cup.html.

Comparative Studies in Society and History

(C1989 Society for Comparative Studies in Society and History

ISTOR and the JSTOR logo are trademarks of JSTOR, and are Registered in the U.S. Patent and Trademark Office. For more information on JSTOR contact jstor-info@umich.edu.

C2002 JSTOR 


\title{
The Economics of Intervention:
}

\section{American Overseas Investments and Relations with Underdeveloped Areas, 1890-1950}

\author{
JEFFRY A. FRIEDEN \\ University of California, Los Angeles
}

For five hundred years relations between developed and underdeveloped societies have been crucial to international politics. Much of modern world history has to do with the ebb and flow of direct political control of underdeveloped societies by the Great Powers, and with conflict among developed nations over contested underdeveloped areas.

The role of economic forces in imperial intervention has long been a major analytical issue. Despite the obvious importance of a careful specification of the economic interests involved, however, the debate is ustally organized around an assessment of the political implications of such crude aggregate categories as trade and investment, as if all trade were in the same goods and all investment in the same sorts of assets. Yet it is precisely the differences among various economic activities that make economic explanations of political affairs useful and that are the focus of modern political economy.

Analysis of the economic motives in imperial expansion and contraction demands a differentiated approach to economic aims, for the political implications of economic activities vary. This study thus explores the political ramifications of different economic interests and concludes that sellers of uncompetitive merchandise and investors in primary production for export will be more prone to support imperial intervention and direct colonialism than will competitive exporters, investors in production for the local market, and lenders to foreign governments.

By way of example, the article examines the progress of American policies toward the underdeveloped world as they evolved from a pale Caribbean imitation of classical European imperialism into a new form of Good Neighborliness. The principal determinants of the shift in American policy, it is

The author acknowledges with thanks the comments and suggestions of Richard Baum, Leonard Binder, David Dollar, Stephan Haggard, Robert Jervis, Miles Kahler, Paul Kennedy, David Lake, Manuel Pastor, Ron Rogowski, John Ruggie, Richard Sklar, Jack Snyder, Kenneth Sokoloff, Michael Walletstein, and David Wilkinson.

0010-4175/89/1311-2447\$5.00 1989 Society for Comparative Study of Sociery and History 
argued here, were socioeconomic development in the "backward" regions and the interrelated change in the kinds of economic interests that Americans held in the developing areas. Until World War I, American investments in the underdeveloped world were primarily in plantation agriculture or mineral extraction for export, and most of the host regions were at low levels of development; standard United States policy was one of intervention and incipient colonialism. By the late 1920s, most of the areas of major economic concem to the United States had developed quite substantially, and American investments had become less concentrated in primary production for export and had moved toward government lending and industrial production for the local market; United States policy moved away from intervention and became firmly anticolonial. Although the argument is made solely for the American case, there is evidence that the framework developed here can usefully be applied to the European colonial powers as well.

Section I briefly outlines the inadequacy of most treatments of the economic factors in imperial policy, then presents a differentiated picture of the political influence of metropolitan economic interests and a rudimentary model of how these interests interact with socioeconomic development in the periphery. Sections II and III describe the United States policies toward the underdeveloped world as they evolved from an early protocolonialist pattem to later anticolonialism, arguing that carefully specified economic factors provide a good explanation of the phenomenon. Section IV addresses alternative explanations of the American experience and finds them wanting; it also discusses the shortcomings of the economic approach. Section V explores possible applications of the framework to the analysis of other imperial experience, and points to parallel or similar attempts in the recent literature.

\section{THE ARGUMENT}

The expansion of European economic interests and the extension of European politicomilitary influence to the rest of the world between 1500 and 1900 constituted a complex process that has given rise to major analytical debates. Scholarly disputes center on the nineteenth-century experience, and on two interrelated issues: the relative influences of metropolitan and peripheral conditions, and the importance of economic factors.

One dimension of the debate has been whether nineteenth-century colonialism grew out of conditions within the imperial powers themselves or was primarily a response by them to local conditions in the areas they annexed. Although thirty years of controversy and research seem only to confirm the obvious compromise answer-imperial policy was driven both by domestic factors and by developments in the periphery-historians have in the process developed clear and sophisticated analyses of the interaction of peripheral and metropolitan events. ${ }^{\prime}$

I John Gallagher and Ronaid Robinson, "The Imperialism of Free Trade," Economic History 
A second dimension of the debate, on the relative importance of economic aims in metropolitan policy, remains underdeveloped. Supporters of economic interpretations generally present laundry lists of individuals, firms, or industries that gained from and/or supported imperial expansion, while opponents of economic approaches trot out catalogues of instances in which material interests were ignored or contravened. The simple separation of the analytical categories into undifferentiated economic interest and equally undifferentiated political influence allows each side to set up and knock down ludicrous targets. Meanwhile, the analytical tools brought to bear on the issue are so blunt that virtually any independent variable can be bludgeoned into association with virtually any dependent variable.

The terms of the debate over economic factors in colonial expansion can be clarified by formulating systematically the underlying predictions of an economic interpretation of North-South relations. We need to construct a rudimentary framework for assessing the differential costs and benefits of imperial intervention, and to focus on the diverse impacts of intervention on various types of metropolitan economic interests. The purely economic approach can be used as a starting point not because nothing else matters but to see how far it can be taken rigorously before it needs to be amended.

We assume simply that the state represents the interests of nationals with overseas assets and markets. This assumption is of course unrealistic, but the alternatives are even less attractive. ${ }^{2}$ For our purposes it will suffice to look only at the interests of those with a direct stake in foreign economic affairs. We consider first the costs of imperial intervention, and then the benefits it brings to imperial economic actors.

The costs of intervention to the imperial power are primarily a function of the resistance encountered, which generally depends on the strength of the local state. The level of political development and cohesion of an area is a fairly good measure of the costs of annexing it, and helps explain the decisions of metropolitan nations in moving into particular locales. Of course, the

Review, 2d ser., 6:1 (1953), 1 -15; for the ensuing debate, see W. R. Louis, ed., Imperialism: The Gallagher and Robinson Controversy (New York: New Viewpoints, 1976). Treatments of the debates and of the historical evidence include D. C. M. Platt, Finance, Trade, and Politics in British Foreign Policy, 1815-1914 (Oxford: Clarendon Press, 1968); P. J. Cain, Economic Foundations of British Overseas Expansion, 1815-1914 (London: Macmillan, 1980); Tony Smith, The Pattern of Imperialism (Cambridge: Cambridge University Press, 1981); and Michael Doyle, Empires (Ithaca: Cornell University Press, 1986). An important example of the new historical work is A. G. Hopkins, An Economic History of West Africa (New York: Columbia University Press, 1973).

2 Simple calculations of imperialism's net benefit to the imperial nation are not very telling, since the bencfits mighe accrue to powerful groups while the costs are bome by powerless taxpayers or footsoldjers. Differing intensities of interest are so difficult to measure that the calculation of just how important foreign economic policy is to various domestic actors is nearly impossible. Stanley Lebergott, "The Returns to U.S. Imperialism, 1890-1929," Joumal of Economic History, 40:2 (June 1980), 229-252, is a fascinating attempt in this mode; unfortunateby, the author pays more attention to the potentially uneven distribution of costs and benefits within the backward areas than he does to the same problem in the United States. 
annexation of areas not profitable in themselves may be rational if they give better access to more profitable areas; the British themselves often explained much of the growth of the British Empire as an attempt to secure the lucrative Indian jewel.

The benefits of intervention depend on the nature of metropolitan economic interests in the area in question. Each point on the spectrum of traditional international economic activities - trade, direct investment, lending to governments - has diverse political implications.

It is first of all important to distinguish between general and specific economic aims. Respect for property rights and general business procedures benefits a broad range of economic actors, including local investors where they exist. Inasmuch as intervention or annexation establishes or restores property rights widely shared and broadly supported by local and metropolitan. business communities, we expect the enforcement of property rights to be a common reason for the use of imperial force ${ }^{3}$ Where normal business conditions in a peripheral area bave broken down or have been challenged, most modern business interests have supported intervention: bondholders, plantation owners, and manufacturers can all agree that metropolitan annexation was preferable to peripheral expropriation.

Imperial power may also be used to extract concessions specific to certain economic interests. In this regard, the potential benefits of intervention vary in accordance with the character of the economic activities involved.

Those engaged in trade pure and simple, performing an entrepôt function, are concerned to maximize commerce through their facilities. Coercion can serve to increase demand for commercial and allied services (insurance, shipping). Pressures along these lines help explain some portion of classical mercantilist policies, which forced colonial trade to use metropolitan ports and ships.

Goods producers want to sell their output at high prices and buy their inputs at low prices. While commercial policy can achieve these goals indirectly, state power can be used more directly to establish and protect exclusive markets and sources of supply in foreign lands. Other things equal, political manipulation to obtain favored export markets or access to natural resources will be less attractive to highly competitive producers than to uncompetitive ones. This is simply another way of noting that those able to undersell their competitors favor freer trade than those who cannot; excluding competitors from annexed territories is a form of trade protection, and we expect it more from uncompetitive than from competitive producers. ${ }^{4}$

3 Charles Lipson, Standing Guard: Protecting Foreign Capital in the Nineteenth and Twentieth Centuries (Berkeley: University of California Press, 1985), 8-26, summarizes the nineteenth-century experience. There are obvious free-rider problems rajsed by one nation's enforcement of property rights that could benefit economic agents from all nations; an exploration of this aspect of nineteenth-century colonial policy is unquestionably needed.

4 Although a variety of explanations of this common observation can be adduced, the one that 
Overseas investments can be divided into three broad types: exploitation of local resources for export, production for the local market, and lending to governments. ${ }^{5}$ The degree to which intervention will aid foreign investors varies with the type of investment. The likelihood of a peripheral threat to the investor and the ability of metropolitan intervention to mitigate effects of such peripheral threats both depend fundamentally on the degree to which the assets that make the investment profitable can be seized or protected. This in turn is largely a function of how tangible the foreign investor's assets are.

Foreign investors in primary production for export are more vulnerable to local attack, and can be more easily defended, than other foreign investors; they are the most interventionist of the lot. The economic utility of such investments stems almost entirely from the investor's rights to the land or natural resource involved. The tangibility of the investor's principal asset, the physical property itself, makes it fairly simple both for host societies to threaten such easily appropriable physical assets and for metropolitan countries to intervene to ensure or enhance the profitability of their ventures. The potential negative effects of such intervention are minimal because foreign investors in mineral extraction and agricultural production for export have few local concerns other than the security of a real asset that is generally quite separate, both geographically and economically, from the host economy. ${ }^{6}$

Foreign investors in production for local markets or in government loans hold assets that are far less tangible, and thus far less profitable for host societies to seize and far more difficult for military intervention to protect or enhance. The economic utility of foreign direct investment in local production is related primarily to its access to the technology, marketing, and manage-

holds up best to theoretical scruciny is that competitive producers have more reason to fear retaliation than do uncompetitive producers. Global free trade is attractive to those who would dominate markets under such circumstances, and, although they might benefit even more by exclusive access to a particular market, their desire for exclusiveness in one area will be outweighed by the fear that it would cause other areas to be sealed off to them. On the other hand, less competitive producers could easily calculate that all of one market is better than very little of all markets, and would be more likely to ignore the attractions of global free trade in favor of smaller but protected markets. It should also be noted that annexation makes more sense when the areas involved are complementary rather than competing. A related treatment is $\mathrm{C}$. C. Wrigley, "Neo-mercantile Policies and the New Imperialism," in The Imperial Impact, Clive Dewey and A. G. Hopkins, eds. (London: Athlone Press, 1978), 20 -34. The considerations here assume that socioeconomic rigidities make increasing the profits of existing producers more feasible than the more efficient alternative of movement into new economic activities. The assumption is reasonable, and can be justified either on the sector-specificity of physical or human capital or on the uncertaincy attached to the adjustment process.

5 Grant Reuber, Private Foreign Investment in Development (Oxford: Oxford University Press, 1973, 72-80), makes a related distinction among "export-oriented," "'market-development," and "government-initiated" multinational corporations.

${ }^{6}$ This tendency is visible both historically and today: One recent study has shown that while extractive industries represented only 15 percent of foreign firms in the developing world in 1967, they accounted for 35 percent of the firtns expropriated there between 1960 and 1976 (Stephen I. Kobrin, "Foreign Enterprise and Forced Divestment in LDCs," International Organization, 34:1 (Winter 1980), 76 . 
ment expertise of the headquarters. ${ }^{7}$ As for loans, they represent nothing more than a contract between borrower and lender; the asset is only a legal agreement. For this very reason, international financial markets have developed mechanisms to ensure that legal commitments to creditors can be broken only at great cost to the borrower's future international economic relations. While an expropriated oil well continues to produce, mistreatment of creditors will cut the debtor off from future borrowing and may make normal international trade difficult. Defaults are generally the unplanned result of unforeseen circumstances, and debtors are normally eager to reach an agreement as amicable as possible. The debtor equivalent of expropriation is not default but repudiation, and debt repudiations are extremely rare.

Along the same lines, an extraordinary effort would be necessary to mount an intervention capable of substantially aiding creditors or investors in the local market. Loans to foreign governments and branch factories producing for the local market are neither locationally nor economically separable from the rest of the local society; measures to affect their profitability require broad manipulation of local conditions. Indeed, inasmuch as the disorder accompanying foreign intervention or the distortions introduced by foreign rule might lead to local economic stagnation, creditors and investors in the domestic market would be hurt while primary-production investors might easily carry on. ${ }^{8}$ None of this implies that creditors and local-market investors have

7 As Kobrin, "Foreign Enterprise and Forced Divestment," $80-81$, demonstrates, where the local affiliate uses somewhat standardized technology or techniques, host-country interference may be more likely, but most branch factories rely enough on their home offices to make their seizure relatively unlikely.

8 The notion that foreign creditors are relatively less prone to invoke home-country intervention than are other investors runs so counter to received historical impressions that it is worth defending at more length. First, it is important to distinguish between true home-country intervention for financial purposes and those instances in which loans were made after metropolitan interventions. In the Caribbean before 1930, it was common for the United States to establish effective military and political control of a country such as Haiti, and then call on a New York investment bouse to make a small stabilization loan to the new protectorate, generally with the implicit or explicit guarantee of the United States government. These hardly qualify as instances of financial difficulty leading to military occupation. Second, where real debt problems do develop, the almost universal creditor response is some form of creditors' consortium to attempt to enforce market discipline on the errant debtor; the combined power of international financial markets has usually been far casier to muster, and perhaps more convincing, than gunboats. Before World War $\mathrm{I}$, this action generally took the form of financial contral committees having representatives of all creditor nations; in the interwar years, these were replaced by consortia organized by the League of Nations; since World War $\mathrm{II}_{1}$ the Intemational Monetary Fund has played a similar role. Third, where creditors did use home-country intervention to reinforce claims, the flag was generally shown only briefly to support the creditors ${ }^{1}$ bargaining position. On a few occasions intervention related to local insolvency turned into long-term occupationEgypt in 1882 is the obvious example-but the reasons the metropolitan power stayed usually had little to do with finance. The more common pattern was a brief period of heightened tension, with or without use of force, after which the debtor agreed to some form of creditor supervision in retum for renegotiated terms and, pechaps, new credits. On debtor-creditor relations sec, for example, Herbert Feis, Europe the World's Banker, 1870-1914 (New Haven: Yale University 
never found home-state intervention to be in their interests, only that generally it was a costlier and thus less frequent altemative for them than for primary-production investors. The kinds of surgical strike or selective intervention that could protect a copper mine or sugar plantation were far less attractive to a financier or firm that had invested in, so to speak, the economy and/or the govermment as a whole.

Different metropolitan economic interests, then, have different incentives to recur to imperial force in the underdeveloped regions. Most private economic agents have similar incentives to appeal to their home governments for enforcement of property rights in general, but beyond this, their interests may diverge. In trade, other things equal, internationally competitive producers are less prone to use coercion than uncompetitive ones. Among metropolitan investors, those with facilities in underdeveloped areas that produce raw materials or agricultural products for export are the ones most inclined to interventionism: Their properties are easily attacked and protected. Metropolitan creditors of local governments and investors in production for local markets generally find home-government military force less relevant to their principal concerns.

The determinants of the benefits of foreign intervention are related to determinants of its costs. Intervention-prone investors are likely to be found in societies whose levels of development are relatively low, and whose states are more likely to be less powerful and authoritative than those of the more advanced developing regions that attract metropolitan lenders and local-market investors. Much foreign direct investment in primary production for export takes place in undeveloped areas, otherwise local entrepreneurs would undertake the investment and local market conditions would be more important. On the other hand, foreign investment to tap the local market presupposes a local market that has achieved a minimal level of commercial and infrastructural development. Similarly, since much foreign direct investment of this type is made in an attempt to jump local tariff barriers, it often also presupposes a local government capable of imposing and enforcing trade protection. By the same token, governments in more advanced peripheral countries are more likely to be technically, politically, and economically able to meet their obligations to foreign creditors and more capable of resisting coercion, thus making coercion less attractive. Economic development tends both to rajse the costs of intervention to a foreign power and to reduce the benefits that intervention might be expected to yield.

Ptess, 1930); Richard Meyer, Banker's Diplomacy (New York: Columbia University Press, I970); and Charles Lipsan, "The Intemational Organization of Third World Debt," International Organization, 35:4 (Autumn 1981), 603-631. For surveys of the Egyptian case, see Roger Owen, "Egypt and Europe: From French Expedition to British Occupation," in Studies in the Theory of Imperialism, Roger Owen and Bob Sutcliffe, eds. (London: Longman, 1972), 195-209; and Doyle, Empires, 208-18. 
We expect that as a metropolitan country becomes more competitive on world markets it will tend to move away from political interference in markets; an increase in the capacity of developing societies to resist domination will produce a similar result. We expect higher levels of intervention from a metropolitan nation with overseas primary investments; once more, the strengthening of local societies in capital-receiving areas and increasing foreign investment in production for local markets and lending to governments will tend to mitigate interventionist tendencies.

A stylized model of the political economy of foreign investment and imperial control in an underdeveloped area begins with the original contact, typically in trade. Once an area is opened to trade, investment follows, normally the establishing of mines or plantations producing for export. As the impact of modern business activity is felt and local forces threaten foreign investors, metropolitan intervention leads to the gradual accretion of colonial control. Over time, economic development progresses, with two central results: Local socioeconomic and political structures are strengthened, and investment opportunities broaden to include government lending and local production for the local market. ${ }^{9}$ The two interrelated processes raise the costs of metropolitan control even as they reduce its benefits, and the region moves gradually toward independence.

To be sure, this scenario describes but one part of the much broader and more complex relationship that exists between developed and developing societies. Our discussion has downplayed the independent importance of the response of the underdeveloped area to external powers. It has virtually ignored the possibility of self-reinforcing strategic interaction, whether between developed and developing areas or among developed areas interested in the same developing ones. The discussion has purposely disregarded military, ideological, and other non-economic factors in metropolitan-peripheral relations. This is not because such elements are unimportant but because the purpose of this essay is less ambitious: to specify carefully the economic factors in imperial policy.

The remainder of this article focuses on foreign investment rather than trade. This is primarily for purposes of simplicity. The sectoral composition of foreign investment is easily measured, while the relative competitiveness of a country's goods is difficult to quantify. While a detailed examination of trade relations is desirable, a preliminary evaluation of the economics of intervention can be undertaken by looking primarily at foreign investments.

What follows is an analysis of the rise and consolidation of American anticolonialism. It focuses on the implications of the two economic factors we

${ }^{9}$ It should of course be noted that there ate many instances in which colonialism did not accelerate, and may indeed have retarded, local socioeconomic and political development. The former Belgian and Portuguese colonies are obvious examples, and others doubtless exist. The generalization is nonetheless valid, if not universal. 
have emphasized: differential investment interests, and peripherai economic and political development. Again, this hardly represents a fully rounded survey of American relations with the underdeveloped world, but it will be seen that the economic approach does well as an explanation of the process, and that it has useful implications for the analysis of other colonial ties.

\section{THE AMERICAN EXPERIENCE: GUNBOAT DIPLOMACY}

As the United States emerged from the Civil War and Reconstruction in the 1880 s and $1890 \mathrm{~s}$, its principal economic concerns in regard to underdeveloped areas were access to markets, opportunities to exploit natural resources, and, where relevant, security for shipping routes. The realities faced by the United States in search of its goals varied from region to region. Most of Africa and much of Asia were already European property by 1900 , and the effort that would have been required for the United States to pry its way into colonial markets was clearly out of the grasp of America's fledgling power. The larger South American countries, on the other hand, were essentially open to American trade; efforts to secure access were thus unnecessary, although attempts to monopolize trade in these countries would certainly have met with superior British force.

Two areas were the focus of American efforts, the Caribbean and East Asia. The former was especially important for the safety of American shipping and certain primary products; the latter was a large market. Both areas were a mix of independent states and colonies, and it was widely believed that American procrastination might allow these two regions to go the way of Africa, into European colonialism. The United States thus moved, from around the time of the Spanish-American War until the 1920s, to control what it could of the Caribbean and East Asia.

In and around the Caribbean, the principal American aim was security for United States shipping and for United States investments in primary products. Local markets were generally small, so that exports were seldom an important issue. The backward and disorganized nature of many Caribbean nations made them prime targets for intervention to enforce property rights. Indeed, the protection of American shipping lanes and of American capital invested in oil wells, mines, farms, and plantations lent itself easily to political intervention also, and the two goals were sometimes reinforcing. Thus, if foreign policy makers decided to intervene for reasons related to the safety of trade routes, real or potential American investors made ideal allies in the struggle to convince often recalcitrant home and foreign audiences.

Well before the Spanish-American War, there was a broad consensus among American economic and strategic thinkers that control of the inevitable trans-Isthmian canal was vitally important to the United States. Once the canal route was secured it was even more obvious that, as then-Secretary of War Elihu Root put it in 1905, "the inevitable effect of our building the Canal 
must be to require us to police the surrounding premises. In the nature of things, trade and control, and the obligation to keep order which goes with them, must come our way. ${ }^{110}$

Deeds followed words, and by the end of World War I the Caribbean region had unquestionably become a sphere of American military and economic predominance. Direct politicomilitary control was exercised at one time or another over Puerto Rico, Cuba, the Dominican Republic, Haiti, Nicaragua, Honduras, and Panama; American troops intervened twice in Mexico; and the threat of force served to cement American influence where force itself was not used. The securing of shipping lines in and around the Caribbean was accompanied by extension of American investments in the region.

In the years after the Spanish-American War, American investments directed at exploitation of the natural resources of the Caribbean region expanded rapidly, especially in Mexico and Cuba. By 1914, American direct investment in the region was over 1 billion dollars, up from about $\$ 300$ million in 1897, and equal to half of all United States overseas direct investment and comprising almost all of American direct investment in developing areas. Nearly all of this investment was in primary production for export, especially in mining and plantation agriculture.

At the same time, American loans to governments in the Caribbean region grew, and indeed policy makers often used financial schemes-dollar diplomacy - to cement American control. By 1914, outstanding American loans to nations in the Caribbean region (defined to include Mexico, Central A merica, Colombia, Venezuela, and the insular Caribbean) were $\$ 310$ million, up from virtually nothing in 1897 and equal to one-third of all American foreign loans and four-fifths of all American loans to the underdeveloped world. ${ }^{11}$ Virtually all of these loans were either tied to primary production for export, especially in Cuba and Mexico, or carried the explicit or implicit guarantee of the United States government and were part of a broader strategy of creating and maintaining a zone of influence in and around the Caribbean.

Primary-production investors frequently appealed for American military intervention in the Caribbean. Sugar planters in Cuba and the Dominican Republic, banana companies in Central America, oilmen and farmers in Mexico all called insistently for United States government intervention, up to and including military force, when local tumoil and/or political opposition endangered their investments.

The politics of overseas investment in petroleum was exemplary of this early period of American emulation of classical European imperialism. In the

\footnotetext{
10 Cited in Dana G. Munro, Intervention and Doltar Diplomacy in the Caribbean, 1900-1920 (Princeton: Princeton University Press, 1964), 113.

'I Data in this is from Cleona Lewis, America's Stake in Internationat Investments (Washington, D.C.: Brookings, 1938), passim.
} 
Caribbean, where American oilmen were predominant and American power adequate, the United States government aggressively defended the position of American oil investors against hostile host governments and sought to limit or exclude rival European oilmen. The State Department thus fought what it perceived as a tilt toward British oil interests on the part of some of Mexico's revolutionary governments. In the early 1920s it supported American oilmen in Venezuela against the Anglo-Dutch interests that originally dominated that country's petroleum. American diplomats pushed the Colombian government in the late 1920s to favor American oilmen; similar efforts were exerted in Peru and Argentina. And, in a series of 1918 notes to his chargé in Costa Rica that summarized the most extreme version of this "closed door" policy, Secretary of State Robert Lansing responded to the news that a British group was negotiating for oil exploration rights: "Department considers it most important that only approved Americans should possess oil concessions in the neighborhood of the Panama Canal. Amory concession does not appear to meet these requirements. Use best efforts to carry into effect this policy." 12

The aggressive American policy met with extraordinary success. Between 1912 and 1922, crude oil production by American companies in the Westem Hemisphere (not including the United States) went from 25,905 to 417,130 barrels per day, while the share of these oil companies in total non-American Western Hemisphere crude production went from less than 50 percent to more than 76 percent. The relative increase was entirely at the expense of the Anglo-Dutch companies. ${ }^{13}$

The other underdeveloped area to which American concern extended was East Asia. Planners looked primarily to maintain or expand the American share of the China trade. This required strenuous efforts to keep the Europeans and Japanese from excluding American goods, and it also led to initiatives aimed at securing geographically important territories for the use of

12 U.S. Department of State, Papers Retating to the Foreign Retations of the United States 1919 [Hereafter cited as FRUS] (Washington, D.C.: Government Printing Office); 1,873 . On the environment, see Munro, Intervention and Dollar Diplomacy, 426-48. On Mexico, the standard study is Lorenzo Meyer, México y Estados Unidos en el conflicto petrolero (1917-1942) (Mexico City: Colegio de México, 1968); see also FRUS 1915, 870-91; FRUS 1916, 741-53; FRUS 1918, 687-751; and FRUS 1920, III, 200-226. On Venezuela, see Stephen G. Rabe, The Road to OPEC: Unired States Relations with Venezuela, 1919-1976 (Austin: University of Texas Press, 1982), 22-42. Two good general overviews are Stephen J. Randall, U.S. Foreign Oit Policy, 1919-1948: For Profits and Security (Kingston: McGill-Queen's University Press, 1985), and Edward Chester, United Srates Oil Policy and Diplomacy (Westport, Conn.: Greenwood, 1983). The relevant volumes of the multivolume histary of Standard Oil of New Jersey are of course crucial: George Gibb and Evelyn Knowlton, The Resurgent Years, 19/1-1927 (New York: Harper and Brothers, 1956), and Herrietta Larson, Evelyn Knowlton, and Charles Popple, New Horizons, 1927-1950 (New York: Harper and Row, 1971). See also Mira Wilkins, "Multinational Oil Companies in South America in the 1920s,"'Business History Review, $48: 3$ (Autumn 1974), 4l4-46.

13 Leonard M. Fanning, American Oil Operarions Abroad (New York: McGraw-Hill, 1947), $204-7$ 
American traders and, in some instances, for the use of American investors in developing foreign agricultural facilities.

By the turn of the century, the United States government was aggressively insisting upon its right to equal access to Chinese economic opportunities, most notably in Secretary of State John Hay's famous Open Door Notes of 1899 and 1900. In China, as in the Caribbean, policy makers aggressively asserted American rights to full and equal access to the trade of the Middle Kingdom. And as in the Caribbean, the United States government often used American loans to push its way into the Chinese market and into the ranks of the Great Powers. Finance was thus largely a tool of policy makers in pursuit of commercial opportunities. From 1907 until 1911, the State Department attempted to force the entry of American financiers into existing or contemplated consortia of European and Japanese banks involved in loans to Chinese railways and the Chinese govemment. The first major success along these lines - the admission of an American contingent made up of J. P. Morgan and Company, railroadman E. H. Harriman, the First National Bank, the National Cit Bank, and the firm of Kuhn, Loeb into a Anglo-German-French group engaged in financing a Chinese railroad-was achieved only when President William Howard Taft directed a point-blank and insistent personal message to the Chinese regent demanding American entry.

Despite some initial success, dollar diplomacy in China ultimately collapsed under the overwhelming weight of stronger rivals from Europe and Japan, as well as from the turmoil that accompanied the nationalist revolutionary ferment of the teens. Nonetheless, the ties among diplomatic influence, dollar loans, and access to the Chinese market were clear to all involved. ${ }^{14}$

After World War I American attention broadened to petroleum resources within the empires or spheres of influence of the major European powers. American oilmen and diplomats, concerned about the apparent depletion of American reserves, attempted to break into promising areas that were under the "protection" of European rivals. The American attack on colonial and semicolonial preferences focused on the Middle East and the Netherlands East Indies.

Most of the promising oil properties of the Middle East were indeed in British hands, either as part of the territories mandated to the British by the League of Nations or lying in spheres of British influence. Throughout the region, from Suez to Kerman and from Kirkuk to Oman, American oil companies found themselves unable to operate. Despite British dissimulation on the point, there was clearly a conscious policy to reserve the region to the Anglo-Persian Oil Company and Royal Dutch Shell, with some French participation allowed. In Holland's East Indian colony, a similar policy of excluding American firms was pursued.

14 Herbert Croly, Willard Srraight (New York: Macmillan, 1925), 269-454; Michael Hunt, The Making of a Special Retationship (New York: Columbia University Press, 1983). 
The United States government fought British, French, and Dutch exclusion of American oilmen on two fronts. First, it protested vigorously to the European states that their policies were clear violations both of generally accepted open-door principles and of such international agreements as the League of Nations mandates and the Treaty of Sèvres, which dismantled the Ottoman Empire. The principles involved were less than clear, however, since the United States had hardly been pursuing an open door in the Western Hemisphere and had refused either to join the League or to sign the Turkish peace treaty. Second, and more pointed, the United States government began refusing oil leases on federal land to firms from countries deemed "nonreciprocating," most prominently to Royal Dutch Shell.

Under relentless American pressure, the British, French, and Dutch gradually gave way. In July 1928, the governments of the Netherlands and the United States reached formal agreement on American access to the petroleum of the Netherlands East Indies; in the same month, the famous Red Line Agreement gave an American group a share of the Anglo-Dutch-FrenchGulbenkian monopoly in the former Ottoman Empire. In Kuwait, Romania, Persia, and elsewhere, American oilmen were permitted some degree of access. The principled American stand on the open door in petroleum lasted precisely as long as it took for American oilmen to be let in; once this aim was accomplished, the United States was perfectly content to see the door slam shut. ${ }^{15}$

From 1890 until the 1920s, then, the pursuit and growth of American political and economic influence in the underdeveloped world followed a more or less coherent and unified pattern. American policy makers were primarily concerned to secure markets for American goods, and to protect American raw materials and agricultural investments. The pattern was tinged with the use of force. Where possible, as in the Caribbean region, the United States established economic and political predominance. Where other colonial nations had beat the Americans to the punch, as in the Middle East and the Dutch East Indies, the government attempted to force closed doors open long enough for Americans to enter.

\section{THE AMERICAN EXPERIENCE: TOWARD DECOLONIZATION}

After World War I the advance of socioeconomic development in the colonial and semicolonial areas most important to the United States began to make American military intervention and political control both less practicable and less essential. On the one hand, the development of local capitalism-spurred in many cases by the initial foreign contact-made local elites both more

15 See, for example, United States Senate, Special Committee Investigating Petroleum Resources, Diplomatic Protection of American Petroleum Interests in Mesopotamia. Netherlands East Indies, and Mexico (Washingcon, D.C.: Government Printing Office, 1945), 1-51; FRUS 1919. II, 250-62; FRUS 1920, II, 649-75; Chester, United States Oil Policy. 214-76; Fanning, American OAL Operations Abroad. 85-99; and Gibb and Knowlton, Resurgent Years, 247-3I7. 
reliable and more capable of resistance. On the other hand, local economic development extended the range of real or potential foreign economic interests into activities for which home-country military intervention made less sense.

The years from 1910 to 1930 were indeed a time of momentous social, economic, and political change for what we now call the third world. Modern industry, modern socioeconomic systems, and modern nation-states all began to emerge in Latin America and parts of Asia and the Middle East. By the 1930s most of Latin America was involved in the vigorous construction of strong states and industrial economies, and also by 1930 urban centers held about 17 percent of Latin America's total population, a proportion roughly equal to that of Europe (excluding England) in the 1880s. ${ }^{16}$ And in the Middle East, as socioeconomic and political development spread, so too did nationalist movements, beginning before World War I and continuing through the interwar period.

The march of national socioeconomic and political development in the third world made American military intervention both less feasible and less necessary. Even as stronger national polities raised the costs of the use of force, they reduced the likelihood of the kinds of unpredictable extra-legal attack on American property that had often led to the use of American military power. Indeed, to a certain extent the decline of the old policy tracked the process of economic and political development: Mexico and the larger South American nations in the 1920s, Venezuela and the Caribbean region in the 1930s and 1940 s, the Middle East only in the 1940s and 1950s.

As socioeconomic development progressed, opportunities available to American investors abroad changed accordingly. A new set of overseas American economic interests in the third world produced new kinds of investors: direct investors interested primarily in local markets, and portfolio investors lending to strong national governments. Ac the same time, the increased competitiveness of American industry led to gradual pressures for freer trade: In the late 1930s the United States began reducing its trade protection and started pushing the European powers to open their colonial doors.

There was a dramatic change in the kinds of American investment in the developing world. In 1914, virtually the entirety of American investments in the underdeveloped areas had been directly or indirectly tied to primary production for export. Total direct investments in developing areas were $\$ 1.3$ billion, of which nearly $\$ 1$ billion was in Cuba and Mexico, almost all of it linked to mining and agriculture. By 1929 the picture was very different. Direct investments in Latin America, Africa, and Asia (excluding Japan) were about $\$ 4$ billion. Of this direct investment, $6 \mathrm{l}$ percent ( $\$ 2.4$ billion) was still

\footnotetext{
16 Paul Bairoch, The Economic Development of the Third World since 1900 (Berkeley: University of California Press, 1975), 149-51.
} 
in primary production $\$ 785$ million in mining, $\$ 754$ million in oil, and $\$ 860$ million in agriculture). But almost entirely new were the major American investments in manufacturing, sales, and utilities; these categories accounted for 34 percent of all American direct investment in the less developed countries (LDCs), a total of nearly $\$ 1.4$ billion (the remainder was miscellaneous or unclassified). On the portfolio investment side, outstanding American loans to the LDCs totalled $\$ 2$ billion in 1929 , up from $\$ 310$ million in 1914; most of the growth in lending was in South America and Asia, which together owed about $\$ 1.6$ billion to Americans. ${ }^{17}$

American economic interests in Africa, Asia, and Latin America had moved away from investments in primary production for export and toward investments in production for local markets and loans to governments. While almost all of the $\$ 1.6$ billion in United States investment in the LDCs in 1914 was in or tied to extractive industries and agriculture, by 1929 over half of the $\$ 6$ billion total was invested in production for local consumption or loans to local governments.

The new investment interests were far less prone to appeal for or support home-country intervention in the political affairs of nations whose markets they were assiduously trying to cultivate than were the earlier investors in primary production. Virtually all of the new nonprimary direct investments were oriented to sales in the burgeoning markets of the more advanced LDCs. By the same token, almost all American loans to Latin America, Africa, and Asia were to national, state, and local governments. The marines were of little help in expanding the Colombian market or forestalling a Brazilian default. Both direct investors and lenders resented and ridiculed the old-line rawmaterials and agricultural interests for their insensitivity to local conditions and their constant calls for American intervention. This attitude, in interaction with the increased international competitiveness of United States industry, reduced the need for exclusive access to markets.

Some figures underlying the trends discussed bere are displayed in Table l, which presents a few simple indicators of United States overseas investment and military intervention from 1890 to 1950 . There is no pretension to quantitative rigor here, for obvious reasons, and the table looks only at overseas investment, thereby ignoring such crucial but unavailable indicators as local socioeconomic development and American trade competitiveness. Nonetheless, the table does indicate some broad trends. Investments in primary production dominated United States assets in the underdeveloped world in both 1897 and 1914, although the trend was toward diversification. (The importance of loans in 1914 is misleading, since almost without exception they

17 Figures calculated from Lewis, Americ4's Stake, 654-55; and United States Department of Commerce, American Direct lavestments in Foreign Countries (Washington, D.C.: Govemment Printing Office, 1930), 18-28, 29-50, et passim. 


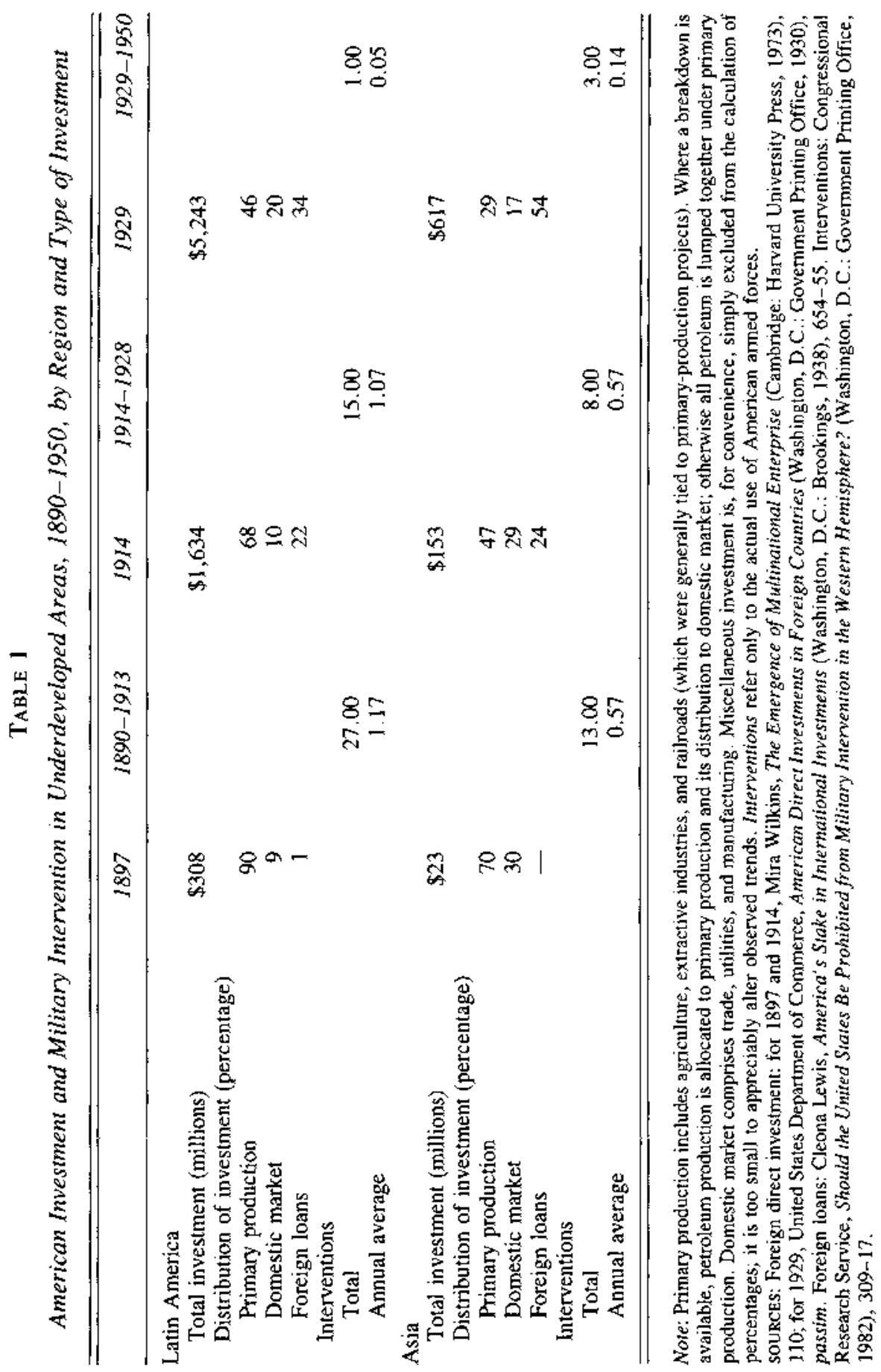


were tied to American-owned agricultural or mining investments in Mexico, Cuba, and the Philippines.) By 1929 in both Latin America and Asia, loans to governments and direct investments to tap local markets had come to dominate American assets. The decline in military intervention is also striking and as expected. Although Table 1 is hardly rigorous proof of the present argument, it does underline the importance of the interrelationships we have discussed.

The reason for the general timing of the shift in both economic interests and policy is clear: World War I. The war led to the first great bout of import substitution in the developing world, as normal channels of supply and demand were disrupted; it helped begin in eamest the march of industrialization that would speed up significantly during the Great Depression. World War I also dramatically accelerated the expansion of modern American enterprise into the developing areas, and especially Latin America. The Europeans practically ceased exports and overseas lending and investing in 1914, and only began again, in greatly reduced amounts, a decade later. In the interim, American investors had filled the vacuum, and conditions had been created for the subsequent change in United States government policy.

That change in policy was most evident in Latin America, where the combination of local socioeconomic development and shifts in American economic concerns drew the United States government away from intervention. In the Middle East, where major petroleum reserves were discovered, America's oilmen became leading actors despite rear-guard European attempts to forestall them, and once the position of the American firms was established, official pressure let up. In both areas, policy moved away from intervention and control and toward a more general reliance on the competitive edge American industry and finance had come to enjoy.

Thus, United States policy toward the underdeveloped regions evolved, with many diversions and digressions to be sure, toward a new, anticolonial standard in the 1920s and 1930s. In 1923 Secretary of State Charles Evans Hughes moderated the Roosevelt Corollary on the occasion of the Monroe Doctrine's centennial; the point was emphasized by the 1927-30 Morrow Mission to Mexico. In December 1933 Secretary of State Cordell Hull assured the Montevideo Conference of the rise of a new Good Neighbor Policy, the Platt Amendment was repealed in 1934, and President Franklin D. Roosevelt himself attended a 1936 peace conference in Buenos Aires. The August 1941 Atlantic Charter reflected Roosevelt's successful insistence that the British promise "to further the enjoyment by all states... of access, on equal terms, to the trade and to the raw materials of the world." 18

18 See, for example, Joseph Tulchin, The Aftermath of War (New York: NYU Press, 1971), 238-41; Robert F. Stmith, The United States and Revotutionary Nationalism in Mexico, 19/61932 (Chicago: University of Chicago Press, 1972), 244-50; and Richard Gardner, Sterling. Dollar Diplomacy in Current Perspective (New York: Columbia University Press, 1980), 49. 
The role played by Dwight Morrow, a senior partner in $\mathbf{J}$. P. Morgan and Company, in the evolution of American policy in this period is illustrative and instructive. In the early 1920s Morrow spent much of his time in Cuba on behalf of the Morgan firm, both to secure the house's investments and to work with the State Department and President Warren G. Harding's Cuban representative in stabilizing the island's finances. The very powerful American investors resident in Cuba, especially the sugar interests, were continually and insistently calling for United States intervention on their behalf. Both Morrow and the presidential representative, however, argued successfully against intervention on the ground that respect for Cuban sovereignty was a far better path to long-run stability. As Morrow put it:

Of course, the Government of Cuba has been, and is, very bad. It is possible-yes, it is probable-that the United States might run Cuba much better. As I get older, however, I become more and more convinced that good govemment is not a substitute for self-government. The kind of mistakes that Americans would make in running Cuba would be different from those that the Cubans themselves make, but they would probably cause a new kind of trouble and a new kind of suffering.

We ought not to use the Platt Amendment to collect the debts, or to enforce the contracts, of private individuals. ${ }^{19}$

That Morrow's position was no aberration within the financial community was confirmed by another senior Morgan partner, Thomas W. Lamont, in 1928:

Good faith on the part of the borrower is far sounder security for a lender than armed forces however great or powerful. The theory of collecting debts by gunboat is unrighteous, unworkable, and obsolete. While I have, of course, no mandate to speak for my colleagues of the investment banking community, I may safely say that they share this view. 20

Morrow implemented his views when he was appointed United States Ambassador to Mexico in 1927, diverging from the intransigent defense of private investors that had characterized most American diplomats in Latin America. Instead, Morrow took a flexible position, settling the longstanding oil rights dispute by recognizing for the first time the sovereignty of Mexico over its resources in return for legal commitments to the oil producers. Morrow took Mexican nationalism as a given and attempted only to ensure general stability and cooperative relations. This involved negotiations on the Mexican government's policies toward the rights of foreign oil companies and over the refunding of Mexico's defaulted debt. ${ }^{21}$

19 Harold Nicolson, Dwight Morrow (New York: Macmillan, 1935), 264-65.

20 Smith, United States and Revolutionary Nationalism. 246. For a related argument, see Emily Rosenberg and Norman Rosenberg, "From Colonialism to Professionalism: The PublicPrivate Dynamic in United States Foreign Financial Advising, 1898-1929," Journol of American History, 74:1 (June 1987), 59-82.

21 Nicolson, Dwight Morrow, 294-347; Smith United States and Revolutionary Nationalism, 244-65; and FRUS 1930, 462-95, all summarize the episode. See also N. Stephen Kane, 
The new American policy was also evident when virtuaily all of Latin America defaulted on debts to United States investors in the early 1930s. By the end of 1934, four-fifths of Latin America's dollar bonds were in default. Yet the Roosevelt Administration did not bring much pressure to bear on the defaulters, and in fact substantial United States government economic assistance was extended to countries in default on their dollar bonds. This reflected recognition that the defaults were largely due to the international economic catastrophe rather than to Latin American bad faith. Correspondingly, it was common throughout South America in the interwar period to distinguish between "good" American direct investors, concentrated in utilities and manufacturing, and "bad" British direct investors, concentrated in railroads and primary production. ${ }^{22}$

When, in 1938, the Mexican government carried its oil policy to its logical conclusion and nationalized foreign oil properties, the American response was once again measured. Protests were filed, suits brought, and some diplomatic pressure applied, but American Ambassador Josephus Daniels was anything but sympathetic to the oilmen. As Daniels wrote to Secretary of State Hull, "I do not agree with the public man who said 'all oil stinks,' but we have seen so many evil practices growing out of the greed for its possession and the power it gives that we are warned to be cautious when we are asked to further the desires of the oil interests." ${ }^{23}$ The 1942 accord that settled the matter was favorable to the Mexicans, and the American oil companies considered the attitude of their government disgraceful.

In Venezuela, as in Mexico before it, the new United States policy gradually gained and was applied. For many years the American oilmen had been on the best of terms with Venzuelan dictator Juan Vicente Gomez, who ruled from 1908 until his death in 1935 . When the regimes that succeeded Gomez in the late 1930s and 1940s began to press for a larger share of petroleum revenues, the oilmen were shocked and chagrined to find the American government arrayed more or less against them and on the side of the Venezuelans.

American minister to Venezuela Meredith Nicholson, appointed in 1935, told Washington that the American oilmen in Venezuela were of the "old school of imperialists" who believed that American military force "ought logically to follow American investments in foreign countries wherever re-

"Corporate Power and Foreign Policy: Efforts of American Oil Companies to Influence United States Relations with Mexico, 1921-1928," Diplomatic History, 1:2 (Spring 1977), 170-98.

22 See, for example, Carlos Diaz Alejandro, Essays on the Economic History of the Argentine Republic (New Haven: Yale University Press, 1970), 32. On the Brazilian and Argentine experiences, see Marcelo de Paiva Abreu, “Argentina e Brasil na década de 30: $O$ impacto das políticas económicas internacionais da Grá-Bretanha e dos EUA," Revista Brasileira de Economia, 38:4 (October 1984), pp. 309-326.

23 Chester, United States Oil Policy, 121 . See especially Meyer, México y Estados Unidos, 198 -264, and E. David Cronon, Josephus Daniels in Mexico (Madison: University of Wisconsin Press, 1960). 
quired by the interests involved." The petroleum executives had, with their blind support for the hated Gomez regime, followed "a policy of shortsightedness verging on stupidity," and they were simply "reaping the fruits of what they had so misguidedly sown." ${ }^{24}$ Nicholson and Lawrence Duggan, head of the State Department's Division of American Republics, fought tenaciously for a more flexible policy toward Latin nationalism. Duggan told his superiors in 1939 that the oilmen had in Venezuela been "arbitrary, highhanded, insensitive, and ruthless," and added, "It must not be permitted them (as occurred in the case of the Mexican dispute) to jeopardize our entire good neighbor policy through obstinacy and short-sightedness. Our national interests as a whole far outweigh those of the petroleum companies." 25

In Venezuela, the shift to the new line culminated in United States government support for a new oil law that gave the host government a far greater share of petroleum revenues than had ever been conceded by American oil interests. With the advice of official and unofficial American representatives, the Venezuelans extracted from the companies a new formula for profit sharing, a fifty-fifty division of petroleum earnings. This nearly doubled the Venezuelan share of oil revenue, and the Venezuelan formula became a standard in profit-splitting accords between American oil companies and host governments. ${ }^{26}$

In the Middle East, major changes in United States policy took place in the 1940s and 1950s. There had been less interest in that area than in the Caribbean, partly because the immense potential for Middle Eastern petroleum development did not become clear until around the time of World War II-in the late 1930s Venezuelan production was about double that of the entire Middle East. World War II, however, stimulated unprecedented concern over the fate of Persian Gulf oil. Yet, much as in the Western Hemisphere, the United States government ended up entrusting oil development to negotiations between private firms and the host countries themselves; when the government intervened it was not to force local acceptance of the companies' demands, but usually to counter the encroachments of the British, French, and Dutch. The process was complex, protracted, and mired in domestic infighting within the United States, but by 1945 or so the State Department had begun to settle upon a Middle Eastern oil policy similar to that developed in Latin America. By 1948 the old Red Line Agreement had been voided. In 1950 the oil companies, under State Department pressure, agreed to a Venezuela-style fifty-fifty split of oil profits with the Saudi regime, and before long such agreements were the Persian Gulf norm. Here, too, the old oil diplomacy

24 Rabe, Road to OPEC, 51-52.

25 lbid., 64.

26 Ibid., 73-93; see also Chester, United States Oil Policy, 144-48. 
of imperial intrigue had been supplanted by more regular ties between host and home governments and firms. ${ }^{27}$

In both Latin America and the Middle East, then, American policy was fundamentally transformed between 1920 and 1950. As local societies developed and American economic interests diversified, the pre-existing patterns of gunboat diplomacy, forceful and often expansionist government defense of private interests, and aggressive diplomatic promotion of the extension of American economic influence gradually eroded. American policy became far more willing to compromise with local leaders and was insistent that the European powers follow suit and decolonize. The new set of policies was formulated in the 1920s and 1930s, and in place by the end of World War II.

\section{OBJECTIONS AND AMENDMENTS}

An economic explanation of American policy toward the developing world holds up to this survey of the evidence. The ability of local nulers to resist intervention or negotiate a settlement effectively and the nature of American economic interests in the developing world correlate well with the character of American policy in the periods in question. No claim is made here that these factors were the exclusive cause of the change in American policy, and it is worthwhile to see whether other potential explanations are more convincing.

We can first dispose of two popular explanations of the shift in policy: American ideology and American party politics. The evidence examined here provides little or no support for the emphasis, common to many Marxist, liberal, and realist accounts alike, on the power of the open-door idea as a motive force in America's international behavior. In the Caribbean from the Spanish-American War until the 1930s, the door was often closed to European competition; in the Middle East in the 1920s, American pressure forced colonial exclusion to be dropped only long enough to permit a few American petroleum firms entry; in a few areas, such as China, the open door was followed with some coherence (although even there the received wisdom receives less than firm support from historians). ${ }^{28}$ Nor does a more general "liberal" ideology seem to have mattered much either in the first phase of America's expansion or in the new age that might be dated to the Morrow Mission. Neither set of policies was motivated by some general belief in the magic of the marketplace; both tolerated and even encouraged (very different kinds of) government intervention in economic affairs.

27 Irvine Anderson, Aramco, the United States, and Saudi Arabia (Princeton: Princeton University Press, 1981), is the best single source on the Saudi case; on the fifty-fifty agreement, for example, see pp. 179-97. See also Michael 8. Stoff, Oit, War, and American Securiry (New Haven: Yale University Press, 1980); and Aaron Miller, Search for Security (Chapel Hill: University of North Carolina Press, 1980)

28 For a suggestive study, see Irvine Anderson. The Standard Vacuum Oit Company and United States East Asian Policy, 1933-1941 (Princeton: Princeton University Press, 1975). 
Party politics also provides little or no explanatory assistance. The Democratic administration of Franklin Roosevelt, for example, espoused policies in the Caribbean and the Middle East that had far more in common with those of its Republican predecessors than with the Woodrow Wilson Administration in which Roosevelt himself had served. Despite some divergences, the American administrations before 1920 pursued strikingly similar policies, just as their similarities outweigh differences in the interwar evolution of a new policy orientation. Of course, the political affiliation of the makers of foreign policy did matter - the spate of New Dealers who flooded into Washington after 1933 had an impact even in the State Department-and yet most foreign-policy decisions were remarkably immune from day-to-day partisan pressures.

A geopolitical analyst might argue that foreign economic policy was only an unimportant adjunct to military aims, and that economic assets and tactics were mere tools in the quest for national security. Thus, some maintain that the dollar diplomacy that helped sweep the Europeans out of the Caribbean was but a minor component forwarding America's true military goals. It is also asserted that the solicitude with which American policy makers treated the nationalistic Mexicans and Venezuelans in the late 1930s and during World War II was a direct result of American apprehension over German and Japanese influence in the Western Hemisphere; if American oilmen had to be sacrificed to secure the nation's military backyard, this was a small price to pay.

There is no question that those responsible for American foreign policy were acutely mindful of America's strategic position in their dealings with underdeveloped areas. Yet it is one thing to point to the expressed circumspection of policy makers, and quite another to argue for an analytical explanation of changes in American policy in which geopolitics is the causal variable. For one thing, it is virtually impossible to derive a country's geopolitical "needs" a priori; the notion is an amorphous one that is often simply expanded to include economic interests and other factors the analyst deems important. To weigh geopolitical interpretations of imperial intervention against economic interpretations would require a theory of imperial intervention that carefully specified the geopolitical conditions that could be expected to lead to intervention, colonialism, or decolonization. So far no such theory has been advanced.

In the American case, geopolitical explanations of American policy in the developing world are ad hoc and often inconsistent. The same cause is used to explain different effects: fear of European infiuence led first to gunboat diplomacy, then to the Good Neighbor Policy twenty years later. Different causes are invoked to explain the same effect: American interventionism in the Caribbean before World War I responded to external threats, but that in East Asia did not.

Geopolitics may provide a useful approximation of the way policy makers 
think about the world, but it does not appear to provide much in the way of rigorous analysis. In one context, fear of external powers led to a tightening of control and a heightening of the importance of economic goals (the Caribbean before World War I); in another setting, an external threat led to a loosening of control and lessening of the importance of economic aims (Mexico in 1938); in a third context, petroleum itself became a strategic good and a prime mover of American policy (the Middle East in the $1940 \mathrm{~s}$ ). We have no way of knowing what role specific security considerations actually played in these instances, and are at even more of a loss when, as in the Morrow Mission, there seems to be little or no geopolitical significance to the events in question. ${ }^{29}$

But even a strong version of the economic explanation could not deny the importance of strategic, ideological, and other forces in relations between developed and developing areas. Any list of reasons for the American interventions in Grenada and Nicaragua, to take more recent examples, would place economic factors far down. The argument here is not that only economic factors matter in intemational relations, but rather that they do matter, and that the ways in which they matter are amenable to careful specification and fruitful study.

A strictly economic framework would still need to make allowance for the rigidity and persistence of entrenched institutions. ${ }^{30}$ Economic evolution in the metropolitan country and the colonial area may reinforce social actors interested in change, but social interests in the pre-existing arrangement may make the transformation lengthy and bitter, as indeed much of Europe's experience with decolonization was. Firms or settler communities that grew up under colonial preferences and depended on them fought to retain the system they relied on; they found allies in the bureaucracies similarly linked to the colonial system. ${ }^{31}$

On a related note, our survey of the American experience indicates that the general economic concerns, policies, and policy shifts we are discussing are not so much specific to individual cases as they are to broad trends and regions. Neither American economic interests in Haiti alone nor Haitian society alone changed enough to explain all of the evolution of United States

29 A neo-realist variant might look at regional geopolitical conditions of a hegemonic and nonhegemonic nature. This, however, raises as many questions as it answers, primarily concerning the relevance of regional balances, the evaluation of extraregional challenges, and the determinacy of the regional response. While the regional approach gives a reasonable account of how rising American hegemony in Latin American in the $1930 \mathrm{~s}$ might have led to loosened control, it does very poorly at explaining why American control over the Philippines was being loosened at the same time despite setious regional challenges to the American position. For a more detailed evaluation, see my "Oil and the Evolution of U.S. Policy toward the Developing Areas, 19001950," in Oit in the World Economy, R. W. Ferrier, ed. (London: Croom Helm, forthcoming).

30 This point is related to that made in a different context by Stephen Krasner, "State Power and the Structure of Intemational Trade," World Politics, 28 (April 1976), 317-347.

31 Ian Lustick, State-Building Failure in British Ireland and French Algeria (Berkeley: Institute of Intemational Studies, 1985). 
policy toward that country; America's Haitian policy changed along with more general changes in the Caribbean and Latin American region. The gradual cumulation of changed interests will normally take quite some time to assert itself; because building new policies and institutions has a cost, pressure for change will tend to grow out of and be applied regionally and across a broad spectrum of issues, rather than on a limited subset of policies in a small geographical area.

In this light it is easy to see how the evolution of United States policies toward underdeveloped areas was crucially affected by the rapidity of the change in America's international economic position. The United States went from an industrializing nation to the world's leading foreign investor with extraordinary speed; in a matter of decades the country was transformed from the world's largest borrower to its largest lender. The accelerated pace of American economic change-due both to the economy's inherent dynamism and to the great impetus given by World War I-helped sweep away many of the socioeconomic institutions and policies that had characterized an earlier era and prevented entrenchment of many colonial or semicolonial interests in the private and public sectors. This helps explain why the United States, a latecomer to the race for colonies, was one of the first to abandon it.

Successive waves of disruption in the international political economy between 1914 and 1945 also help explain the strength of the push for decolonization after World War II. The disnuptions in supply and shifts in demand caused by World War I were followed by a boom in international trade and lending in the 1920s, then by the collapse in demand of the 1930s and the supply shocks of World War IL. In most of the developing areas, these events served to expand local production of previously imported goods; the vagaries of the international economy also often forced local governments to extend their activities. The combination of import substitution and greater government intervention in much of Latin America, Africa, and Asia reinforced the underlying economic and political trends that we have identified with decolonization. By 1945, local markets, local production, and local political cohesion were far more advanced in the underdeveloped world than they had been thirty years before.

It may be objected that in this framework two causal variables-the level of local development and the character of American economic interests in the local area-are hopelessly entangled. The point, however, is that the two are fundamentally and inevitably interrelated. Peripheral socioeconomic and political conditions are a major factor in the decisions of metropolitan investors and traders; metropolitan investment and trade have a major influence on local socioeconomic and political development. To try to separate the two would approach an exercise in sterile scholasticism. Our purpose is more practical: to help clarify the historical record on North-South relations with a deductive conception of the political implications of economic factors. 


\section{EXTENDING THE ARGUMENT}

Although we have not presented evidence to extend the argument to the European and Japanese experiences, the clear implication of our discussion is that colonial imperialism was a function of a particular stage of economic development in the third world and of the kinds of metropolitan overseas trade and investments that characterized the eras of colonial expansion. Imperialism was, in other words, a result of the search for raw materials, agricultural products, and markets in precapitalist nations. The end of direct colonialism was in turn a function of economic advance in the developing nations and changing patterns of overseas trade and investment in the industrial ones. Independent third world nation-states arose as capitalism progressed in those areas and international trade and investment diversified.

In fact, some recent scholarship on European imperialism reflects a nuanced appreciation of the role of economic interests in the rise and decline of colonial rule. A few researchers have pointed toward more general conclusions, relating, for example, to the importance of different forms of metropolitan trade and investment ${ }^{32}$ and of business cycles and tariffs. ${ }^{33}$ Other work has looked at specific firms, thereby highlighting the difference between an enterprise such as the British South Africa Company in Northern Rhodesia, whose ownership of mineral rights made it firmly colonialist, ${ }^{34}$ and a diversified multinational such as Unilever, which actually suffered with the lack of colonial tariff autonomy and grew ever more rapidly as the colonies moved toward independence. ${ }^{35}$

Much of the most exciting recent scholarship examines the role of economic factors in specific colonial regions. A. G. Hopkins uses a typology, as he says, "based on the identification and interaction of interest groups" to analyze economic factors in the partition, colonial development, and decolonization of West Africa. ${ }^{36}$ In parallel fashion, B. R. Tomlinson's exam-

\footnotetext{
32 On trade, see Wrigley, "Neo-rnercantile Policies"; on investments, see David FieIdhouse, "A New Imperial System"? The Role of Multinational Corporations Reconsidered," in Imperialism and After, Wolfgang Mommsen and Jurgen Osterhammel, eds. (London: Allen and Únwin, 1986), 225-40; for a comparison, see Miles Kahler, "Political Regime and Economic Actors: The Response of Firms to the End of Colonial Rule," World Politics, 33:3 (April 1981), $383-412$

33 See, for example, William G. Hynes, The Economics of Empire (London: Longman, 1979); and C. W. Newbury, "The Tariff Factor in Anglo-French West African Partition," in France and Britain in Africa, Prosser Gifford and William Roger Louis, eds. (New Haven: Yale University Press, 1971), 220-59. An excellent general essay is P. J. Cain and A. G. Hopkins, "The Political Economy of British Expansion Overseas, 1750-1914," Economic History Review, $2 \mathrm{~d}$. ser., 33:4 (November 1980), 463-490; an important collection of essays is British Imperialism in the Nineteenth Century, C. C. Eldridge, ed. (London: Macmillan, 1984).

${ }^{34}$ Peter Slinn, "Commercial Concessions and Politics during the Colonial Period," African Affairs, 70 (1971), 365-84

35 D. K. Fieldhouse, Unilever Overseas (London: Croom Helm, 1978).

36 Hopkins, Economic History of West Africa, 166, 124-66, 276-79; idem, “Property Rights and Empire-Building," Journat of Economic History, 40:4 (December 1980), 777-98.
} 
ination of Indian economic development in the decades leading up to decolonization helps to clarify the economic underpinnings of the subcontinent's political evolution. ${ }^{37}$ These lines of research seem certain to provide new evidence on the role of economic factors in imperial relations, supplying fresh material to test and refine the concepts discussed here.

\section{SUMMARY}

This essay has presented a framework for the analysis of economic factors in political relations between developed and developing areas. The most relevant considerations in this regard are the potential costs of imperial intervention in enhancing the return to metropolitan economic interests, and the potential benefits that intervention might bring to these interests. The essay has emphasized the differential political implications of various types of metropolitan economic activity, and especially of different forms of foreign investment.

The framework was applied to examine the evolution of American policy toward the underdeveloped world from 1890 until the end of World War II. Before the 1920s the United States was a recognizable, if laggard, runner in the race for colonies. By the 1930s, the country was following a new set of policies toward the developing world, one which would be generalized after World War II. In the previous instance, American military force went almost hand in hand with American economic penetration. In the later pattern, the two grew gradually apart, so that the notion of military intervention to protect American loans to Latin America now seems nearly unthinkable.

The evolution in American policy had two closely related sources. The first was the strengthening of modern economies and nation-states in the developing world, which made intervention less feasible and less necessary. The second was the shift in the kinds of investment made in the developing areas from primary production for export, prone to lobbying for intervention, to production for local markets and lending to local governments, neither of which were conducive to protection by armed intervention. The two sets of pressures for change were interactive.

Our brief discussion of the American case by no means represents a rigorous test of the analytical framework developed here, but it does demonstrate the framework's viability. A preliminary look at the experiences of the European colonial powers demonstrates the potential usefulness of the approach. A further specification of the causal factors at play, and their application to other areas and other eras, seems both possible and profitable.

37 B. R. Tominson, The Political Economy of the Raj, 19/4-1947 (London: Macmjllan, 1979); and B. R. Tomlinson, "Foreign Private Investment in India, 1920-1950," Modern Asian Studies, 12:4 (1978), 655-77. 